\title{
THE INTERNATIONAL CALENDAR
}

2020

\section{AALS Annual Meeting (Association of American Law Schools)}

"Pillars of Democracy: Law, Representation, and Knowledge." Legal education plays essential roles in sustaining the pillars of constitutional democracy. These include: law, its values, and institutions, including the knowledge institutions of which law schools are an integral part.

January 2-5, 2020

Washington, DC, USA

https://am.aals.org/

\section{BOBCATSSS 2020 (European Association for Library and Information Education and Research)}

"Information Management, Fake News and Disinformation." The conference aims to connect theoretical approaches and professional practices by addressing this issue from the perspective of business analysts, information managers, librarians, and archivists.

January 22-24, 2020

Paris, France

http://www.bobcatsss.info/2020/index.php

\section{ALA Midwinter Meeting (American Library Association) \\ January 24-28, 2020 \\ Philadelphia, PA, USA \\ https://2020.alamidwinter.org/}

\author{
ABA Midyear Meeting (American Bar Association) \\ February 12-18, 2020 \\ Austin, TX, USA \\ https://www.americanbar.org/groups/departments_offices/meetings_travel_dept.html
}

\section{Georgia International Conference on Information Literacy (GICOIL)}

The Georgia International Conference on Information Literacy allows participants to engage with one another and learn the best practices for teaching these essential skills to students. Through workshops, roundtable discussions, panels, and networking opportunities, K-12 and higher education faculty, librarians, writing instructors, and teachers can discover how to apply crucial information literacy skills.

February 20-22, 2020

Georgia Tech Savannah Campus, Savannah, GA, USA

https://academics.georgiasouthern.edu/ce/conferences/infolit/

\section{code $\{4\}$ lib}

"The Conference for People Who Code for Libraries." An annual gathering of technologists from around the world, who largely work for and with libraries, archives, and museums and have a commitment to open technologies.

March 8-11, 2020

Pittsburgh, PA, USA

https://2020.code4lib.org/ 


\section{Computers in Libraries}

The focus of the Computers in Libraries conference is on emerging and leading edge technology that allows us to engage with, and bring strategic value to, our user communities. The conference also includes WebSearch University's Academy and the Library Leaders Summit.

March 31-April 2, 2020

Arlington, VA, USA

http://computersinlibraries.infotoday.com/2020/

\section{NELLCO Symposium}

For 2020, NELLCO will be partnering with the Legal Information Preservation Alliance (LIPA) to bring a diverse array of programming and exciting new speakers while maintaining the spirit of the NELLCO Symposium.

April 1-3, 2020

Schenectady, NY, USA

https://www.nellco.org/page/Symposium

\section{ASIL Annual Meeting (American Society of International Law)}

"The Promise of International Law." In a world of increasing polarization and threats to individual and collective security, many turn to international law for guidance and protection, while others consider this body of law and the institutions that apply it ill-equipped to address evolving needs. Has international law lived up to its full potential and is it equipped to safeguard the peaceful coexistence of its subjects, to protect human rights and the environment, and to contribute to the attainment of shared prosperity?

April 1-4, 2020

Washington, DC, USA

https://www.asil.org/annualmeeting

\section{ICOLC (International Coalition of Library Consortia)}

Semi-annual meeting dedicated to keeping consortia informed about issues of importance to directors, governing boards, and libraries of consortia.

April 19-22, 2020

Columbia, SC, USA

https://icolc.net/meetings

\section{SCECSAL XXIV (Standing Conference of Eastern, Central and Southern African Library and Information Associations)} Africa."

"Inclusive libraries and information services toward achieving prosperity for sustainable development in

April 20-24, 2020

Windhoek, Namibia

http://scecsal2020.org/

\section{ALIA National 2020 Conference (Australian Library and Information Association)}

"Courageous and Audacious." Speakers include Australian Indigenous writer Bruce Pascoe; Leslie Weir, Librarian and Archivist of Canada; and David Fricker, Director-General of the National Archives of Australia.

May 4-7, 2020

Sydney, NSW, Australia

https://www.alia.org.au/events/17945/alia-national-2020-conference 


\section{LOEX2020}

"We Can Do It! Building the Best in Library Instruction."

May 7-9, 2020

Ypsilanti, MI, USA

http://www.loexconference.org/

\section{Libraries in the Digital Age (LIDA) 2020}

"Reshaping Identity in the Digital Age: People, Libraries, Data, Technology \& Ethics."

May 19-22, 2020

Inter-University Centre, Dubrovnik, Croatia

http://ida.ffos.hr/

\section{CALL/ACBD 2020 (Canadian Association of Law Libraries)}

"Revival / Rebirth / Re-invention." "Renouveau / Renaissance / Réinvention."

May 24-27, 2020

Hamilton, ON, Canada

https://www.callacbd.ca/Conference

\section{The Teaching Professor Conference}

Tracks include Preparing Your Course, Technology Tools for Teaching, and Online Teaching and Learning. May 29-31, 2020

Atlanta, GA, USA

https://www.magnapubs.com/teaching-professor-conference/

\section{SLA Annual Conference (Special Libraries Association)}

"Be Part of the Movement." The SLA Annual Conference is the premier event for special librarians and information professionals who want to explore the latest challenges and trends in knowledge and information management, refine their skills, connect with colleagues, and meet with leading information product and service providers.

June 6-9, 2020

Charlotte, NC, USA

https://connect.sla.org/ac2020/home

\section{BIALL Conference 2020 (British \& Irish Association of Law Librarians)}

" 'Bodies' in the Library: Sleuthing, Plotting and Making the Case." A "body" can be any puzzle of issue you need to solve, whether it relates to managing resources, engaging users or finding an elegant solution to a tricky problem.

June 11-13, 2020

Harrogate, UK

https://biall.org.uk/annual-conference/conference-2020-harrogate/

\section{ALA Annual Conference (American Library Association)}

As the world's biggest library event, the ALA Annual Conference \& Exhibition brings together more than 20,000 librarians and library staff, educators, authors, publishers, friends of libraries, trustees, special guests, and exhibitors.

June 25-30, 2020

Chicago, IL, USA

https://2020.alaannual.org/

\section{AALL Annual Meeting (American Association of Law Libraries)}

"Unmasking Our Potential." Keynote speaker is Jim Kwik, founder of "Kwik Learning and Superhero You Change Your Brain, Change the World."

July 11-14, 2020

New Orleans, LA, USA

https://www.aallnet.org/conference/ 


\section{LWI Biennial Conference (Legal Writing Institute)}

"Teaching, Writing, and Thriving at All Stages." This broad theme covers a number of topics relating to teaching, scholarship, and professional service.

July 15-18, 2020

Georgetown University Law Center, Washington, DC, USA

https://www.lwionline.org/conferences/2020-lwi-biennial-conference

\section{ABA Annual Meeting (American Bar Association)}

July 30-August 4, 2020

Chicago, IL, USA

https://www.americanbar.org/groups/departments_offices/meetings_travel_dept/future-past-meetings/

\section{SAA Annual Meeting (Society of American Archivists)}

"Archives * Records 2020: Creating Our Future." Joint annual meeting of the Council of State Archivists and the Society of American Archivists. The theme invites us to make visible the ingenuity that is inherent in our work - and to consider how we can leverage our creativity to sustain a future-oriented, vibrant, and intellectually invigorating archival profession.

August 2-8, 2020

Chicago, IL, USA

https://www2.archivists.org/am2020

\section{IFLA World Library and Information Congress (International Federation of Library Associations and Institutions)}

"Inspire, Engage, Enable, Connect."

August 15-21, 2020

Dublin, Ireland

https://2020.ifla.org/

\section{ALLA Conference (Australian Law Librarians' Association)}

"Past/Present/Future."

September 23-25, 2020

Canberra, ACT, Australia

http://allaconference.com.au/

\section{$3^{\text {th }}$ Annual Course of the International Association of Law Libraries (IALL)}

October 4-7, 2020

Toulouse, France

http://iall.org/annual-conference-2/

\section{$10^{\text {th }}$ Shanghai International Library Forum (SILF2020)}

"Building Libraries for a New Age: Perseverance, Transformation and Disruption." The conference will focus on hot issues and topics, the latest research achievents, innovative ideas, advanced technology, and the latest developments related to the theme.

October 14-16, 2020

Shanghai Library, Shanghai, China

http://silf2020.library.sh.cn/en/ 
AoIR2020 (Association of Internet Researchers)

October 29-31, 2020

Dublin, Ireland

https://aoir.org/aoir2020/

2021

AALS Annual Meeting (Association of American Law Schools)

January 5-9, 2021

San Francisco, CA, USA

https://www.aals.org/events/

ALA Midwinter Meeting (American Library Association)

January 22-26, 2021

Indianapolis, IN, USA

http://www.ala.org/conferencesevents/upcoming-annual-conferences-midwinter-meetings

ABA Midyear Meeting (American Bar Association)

February 17-21, 2021

Chicago, IL, USA

https://www.americanbar.org/groups/departments_offices/meetings_travel_dept.html

ASIL Annual Meeting (American Society of International Law)

March 24-27, 2021

Washington, DC, USA

https://www.asil.org/annualmeeting

ACRL Conference 2021 (Association of College \& Research Libraries)

"Ascending into an Open Future."

April 14-17, 2021

Seattle, WA, USA

https://conference.acrl.org/

ALA Annual Conference (American Library Association)

June 24-29, 2021

Chicago, IL, USA

http://www.ala.org/conferencesevents/upcoming-annual-conferences-midwinter-meetings

AALL Annual Meeting (American Association of Law Libraries)

July 17-20, 2021

Cleveland, OH, USA

https://www.aallnet.org/conference/about/future-meetings/

\section{SAA Annual Meeting (Society of American Archivists)}

July 31-August 7, 2021

Anaheim, CA, USA

https://www2.archivists.org/conference 
ABA Annual Meeting (American Bar Association)

August 5-10, 2021

Toronto, ON, Canada

https://www.americanbar.org/groups/departments_offices/meetings_travel_dept/future-past-meetings/

IFLA World Library and Information Congress (International Federation of Library Associations and Institutions)

August 19-26, 2021

Rotterdam, Netherlands

https://www.ifla.org/node/92527

$40^{\text {th }}$ Annual Course of the International Association of Law Libraries

September 2021

Stanford Law School, Stanford, CA, USA

http://iall.org/annual-conference-2/

2022

ALA Midwinter Meeting (American Library Association)

January 22-25, 2022

San Antonio, TX, USA

http://www.ala.org/conferencesevents/upcoming-annual-conferences-midwinter-meetings

ABA Midyear Meeting (American Bar Association)

February 9-15, 2022

Seattle, WA, USA

https://www.americanbar.org/groups/departments_offices/meetings_travel_dept.html

ALA Annual Conference (American Library Association)

June 23-28, 2022

Washington, DC, USA

http://www.ala.org/conferencesevents/upcoming-annual-conferences-midwinter-meetings

AALL Annual Meeting (American Association of Law Libraries)

July 16-19, 2022

Denver, CO, USA

https://www.aallnet.org/conference/about/future-meetings/

ABA Annual Meeting (American Bar Association)

August 4-9, 2022

Chicago, IL, USA

https://www.americanbar.org/groups/departments_offices/meetings_travel_dept/future-past-meetings/

IFLA World Library and Information Congress August 13-9, 2022

Auckland, NZ

https://www.ifla.org/node/92121

Annual Meeting of the Society of American Archivists

August 20-27, 2022

Boston, MA, USA

https://www2.archivists.org/am2022 
ABA Midyear Meeting (American Bar Association)

February 1-6, 2023

New Orleans, LA, USA

https://www.americanbar.org/groups/departments_offices/meetings_travel_dept.html

ACRL Conference 2023 (Association of College \& Research Libraries)

March 5-18, 2023

Pittsburgh, PA, USA

http://www.ala.org/acrl/conferences/futureacrlconfs

AALL Annual Meeting (American Association of Law Libraries)

July 15-19, 2023

Boston, MA, USA

https://www.aallnet.org/conference/about/future-meetings/

Annual Meeting of the Society of American Archivists

July 22-29, 2023

Washington, DC, USA

https://www2.archivists.org/am2023

\section{ABA Annual Meeting (American Bar Association)}

August 2-8, 2023

Denver, CO, USA

https://www.americanbar.org/groups/departments_offices/meetings_travel_dept/future-past-meetings/ 